\title{
Pengaruh Pola Asuh terhadap Perilaku Makan Anak Usia 4-6 Tahun
}

\author{
Noor Maziyati Nida, Fitri Hartanto \\ Bagian Ilmu Kesehatan Anak Fakultas Kedokteran Universitas Diponegoro/RSUP Dr. Kariadi, Semarang
}

\begin{abstract}
Latar belakang. Perilaku makan yang terbentuk saat dewasa diawali oleh perilaku makan di usia anak-anak. Faktor lingkungan terdekat yang berpengaruh pada perilaku makan adalah keluarga diantaranya pola asuh orangtua. Beberapa penelitian menyebutkan terdapat hubungan pola makan remaja dengan pola asuh orangtua.

Tujuan. Menganalisis hubungan pola asuh terhadap perilaku makan anak usia 4-6 tahun.

Metode. Penelitian dengan desain cross-sectional, dilaksanakan di beberapa TK di Semarang dengan subyek orangtua dan anak usia 4-6 tahun yang memenuhi kriteria inklusi dan eksklusi. Pemilihan subyek dilakukan dengan teknik consecutive sampling dengan besar sampel sebanyak 153 subyek. Data perilaku makan diperoleh melalui Children Eating Behaviour Questionnaire (CEBQ), sedangkan data pola asuh melalui kuesioner pola asuh. Analisis data menggunakan uji koefisien kontingensi.

Hasil. Sebanyak 125 (82,4\%) anak mendapatkan pola asuh demokratis, 18 (11,1\%) pola asuh otoriter dan 10 (6,5\%) permisif, 72,5\% di antaranya adalah penyuka makanan dan $27,5 \%$ penghindar makanan. Terdapat korelasi sangat lemah pola asuh demokratis terhadap terhadap perilaku makan $(\mathrm{r}=0,197 ; \mathrm{p}=0,013)$. Terdapat korelasi sangat lemah pola asuh permisif terhadap terhadap perilaku makan $(\mathrm{r}=0,189 ; \mathrm{p}=0,017)$. Tidak didapatkan korelasi yang bermakna antara pola asuh otoriter terhadap perilaku makan.

Kesimpulan. Penelitian ini memberikan informasi dengan menunjukkan adanya pengaruh pola asuh demokratis dan permisif terhadap perilaku anak, tetapi tidak ada korelasi pada pola asuh otoriter. Sari Pediatri 2021;23(3):150-7
\end{abstract}

Kata kunci: pola asuh, perilaku makan

\section{Effect of Parenting Style on Children's Eating Behaviour Aged 4-6 Years Old}

Noor Maziyati Nida, Fitri Hartanto

Background. Eating behavior that is formed as an adult begins with eating behavior at the age of children. The closest environmental factor that affects eating behavior is family, including parenting style. Some studies said there is a relationship between adolescent eating patterns with parenting style.

Objective. Analyze the correlation of parenting style to the children's eating behavior aged 4-6 years

Method. Cross-sectional design was carried out in several kindergartens of Semarang with subjects of parents and children aged 4-6 years who met the inclusion and exclusion criteria. The selection of subjects was done by consecutive sampling technique with a sample size of 153 subjects. Data on eating behavior was obtained through Children Eating Behavior Questionnaire (CEBQ), while parenting style data was through a parenting questionnaire. Data analysis used a contingency coefficient test.

Result. One hundred and twentyfive children (82,4\%) had an authoritative parenting style, 18 children (11,1\%) authoritarian and 10 children $(6,5 \%)$ permissive, of which $72,5 \%$ were food approach and $27,5 \%$ food avoidant. Authoritative had a very weak correlation to children's eating behavior $(\mathrm{r}=0.197 ; \mathrm{p}=0.013)$. Permissive had a very weak correlation to children's eating behavior $(\mathrm{r}=0.189 ; \mathrm{p}=0.017)$. No significant correlation was found between authoritarian parenting on children's eating behavior.

Conclusion. This study provides information by showing the influence of authoritative and permissive parenting styles on the children's eating behavior, but there is no correlation on authoritarian parenting styles. Sari Pediatri 2021;23(3):150-7

Keywords: parenting style, eating behaviour

Alamat korespondensi: Noor Maziyati Nida, Fitri Hartanto T.S. Bagian Ilmu Kesehatan Anak Fakultas Kedokteran UNDIP/RSUP Dr Kariadi, Jl. Dr.Sutomo No16-18, Semarang. Email: ikarsdk@gmail.com 
$\mathrm{P}$ erilaku makan anak berhubungan erat dengan kesehatan anak. ${ }^{1,2}$ Perilaku makan yang terbentuk di usia dewasa, diawali oleh perilaku makan pada usia anak. Faktor yang berpengaruh dan saling berinteraksi terhadap perilaku makan anak maupun dewasa masih belum dimengerti dengan jelas. ${ }^{1,2,3}$

Masalah makan pada anak berbeda dengan orang dewasa dan dewasa muda. Masalah perilaku makan dapat bervariasi dari memilih makanan tertentu, membatasi jumlah asupan, makan berlebihan, sampai terjadinya gangguan makanan yang berimbas pada gangguan pertumbuhan dan perkembangan. Keluhan anak sulit makan menjadi masalah yang sering diungkapkan oleh orangtua ketika membawa anaknya ke dokter. Keluhan ini merata tanpa membedakan jenis kelamin, etnis, dan status sosial ekonomi. Beberapa masalah makan yang sering muncul antara lain, rewel, muntah, terlalu pemilih, fobia makan, makan lambat, dan penolakan makanan. ${ }^{4}$

Mendidik anak merupakan usaha nyata orangtua untuk mengembangkan totalitas potensi pada diri anak. ${ }^{3}$ Pola asuh orang tua adalah cara terbaik yang dapat ditempuh orangtua dalam mendidik anak. Pola asuh dapat juga diartikan cara mengasuh dan metode disiplin orangtua dalam berhubungan dengan anak. Hal ini bertujuan membentuk watak serta kepribadian dan memberi nilai-nilai bagi anak agar dapat menyesuaikan diri dengan lingkungan sekitar. Dalam memberikan aturan pada anak, setiap orangtua akan memberikan bentuk pola asuh berbeda yang dipengaruhi oleh faktor budaya, sosial, ekonomi dan sebagainya. ${ }^{5}$ Baumrind $^{6}$ memaparkan tiga jenis pola asuh berdasarkan dua dimensi pola asuh (responsiveness/kehangatan dan control) yaitu pola asuh demokratis, otoriter dan permisif.

Pola asuh dianggap sebagai karakteristik orangtua yang stabil sepanjang waktu yang dipengaruhi oleh faktor lingkungan dalam pengasuhan anak-anak mereka. Ada beberapa studi yang mengatakan terdapat hubungan antara pola asuh dengan perilaku makan masa remaja. Terdapat penelitian yang menjelaskan bahwa pola asuh otoriter berisiko untuk terjadi gizi lebih untuk dua tahun kedepannya, namun ada juga yang penelitian yang menyatakan tidak ada hubungan di antara keduanya. ${ }^{1}$

Tujuan penelitian ini adalah menganalisis hubungan pola asuh dengan perilaku makan anak.

\section{Metode}

Penelitian cross sectional dilakukan dari Februari 2019 hingga Juli 2019 dengan populasi target orangtua anakanak usia 4-6 tahun yang bersekolah di TK wilayah Semarang. Subjek sejumlah 153 pasangan ibu dan anak usia 4-6 tahun yang memenuhi kriteria penelitian dengan pengumpulan sampel secara consecutive. Kriteria inklusi siswa TK yang masuk sekolah dan didampingi orangtuanya pada saat penelitian dilakukan. Kriteria eksklusi adalah penderita penyakit kongenital, menderita penyakit infeksi yang dirawat di Rumah Sakit, menderita penyakit keganasan, pengisian kuesioner tidak legkap. Informed consent dimintakan dari orangtua kemudian mengisi kuesioner pola asuh dan Children's eating behavior questionnaire (CEBQ).

Analisis statistik dilakukan dengan program SPSS for Windows 15.0. Analisis deskriptif data kategorikal dinyatakan dengan frekuensi dan persentase, sedangkan data numerik dengan rerata dan standar deviasi atau median dan minimum-maksimum. Hubungan antara variabel dilakukan dengan uji koefisien kontingensi, koofisien korelasi dinyatakan dengan $r$ dan kemaknaan dinyatakan dengan p. Persetujuan etik (ethical clearance) didapat dari dari Komisi Etika Penelitian Kedokteran Fakultas kedokteran Universitas Diponegoro, Badan Kesatuan Bangsa dan Politik Pemeritah kota Semarang dan Dinas Pendidikan kota Semarang.

\section{Hasil}

Karakteristik subyek penelitian tertera pada tabel 1 . Sebagian subyek berjenis kelamin laki-laki $(52,3 \%)$ dengan rerata usia 5,37 tahun. Sebagian anak memiliki status nutrisi gizi baik $121(79,1 \%)$ dengan perawakan tubuh normal 135 (88,2\%) anak. Namun dari 153 subyek masih teridentifikasi adanya malnutrisi di usia 4-6 tahun yaitu gizi kurang 8,5\% dan gizi lebih hingga obesitas $12,4 \%$ serta perawakan pendek/stunting (tinggi badan di bawah standar menurut usia) sebesar 11,2\%.

Sejalan dengan penilaian obyektif dari pengukuran antropometri, perilaku makan anak dinilai berdasarkan hasil pengisian kuesioner perilaku makan anak yang diadopsi dari children's eating behavior questionnaire (CEBQ). Kuesioner ini sebelumnya telah dilakukan uji validasi dan reliabilitas oleh salah satu penelitian di Indonesia yang diperkirakan memiliki karakteristik subyek 
Tabel 1. Karakteristik subyek penelitian $(\mathrm{n}=153)$

\begin{tabular}{|c|c|c|c|}
\hline Variabel & $\mathrm{n}(\%)$ & Rerata (SD) & Median (range) \\
\hline Usia (tahun) & & $5,37(0,58)$ & $5,33(4,00-6,83)$ \\
\hline \multicolumn{4}{|l|}{ Jenis kelamin } \\
\hline Laki-laki & $80(52,3)$ & & \\
\hline Perempuan & $73(47,7)$ & & \\
\hline Berat badan (kg) & & $18,90(4,19)$ & $18,00(11,60-36,10)$ \\
\hline Tinggi badan $(\mathrm{cm})$ & & $109,47(5,92)$ & $109,30(96,40-129,00)$ \\
\hline \multicolumn{4}{|l|}{ Status nutrisi } \\
\hline WAZ (BB/U) & & $-0,26(1,45)$ & $-0,50(-3,14-4,68)$ \\
\hline Sangat kurang & $2(1,3)$ & & \\
\hline Kurang & $12(7,8)$ & & \\
\hline Normal & $127(83,0)$ & & \\
\hline Lebih & $12(7,8)$ & & \\
\hline $\mathrm{HAZ}(\mathrm{TB} / \mathrm{U})$ & & $-0,58(0,98)$ & $-0,58(-3,04-2,25)$ \\
\hline Sangat pendek & $1(0,7)$ & & \\
\hline Pendek & $16(10,5)$ & & \\
\hline Normal & $135(88,2)$ & & \\
\hline Tinggi & $1(0,7)$ & & \\
\hline WHZ (BB/TB) & & $0,12(1,69)$ & $-0,06(-2,70-8,40)$ \\
\hline Gizi kurang & $13(8,5)$ & & \\
\hline Gizi baik & $121(79,1)$ & & \\
\hline Gizi lebih & $10(6,5)$ & & \\
\hline Obesitas & $9(5,9)$ & & \\
\hline \multicolumn{4}{|l|}{ Arah garis pertumbuhan } \\
\hline Tidak normal & $24(15,7)$ & & \\
\hline Normal & $129(84,3)$ & & \\
\hline \multicolumn{4}{|l|}{ Pola asuh orang tua } \\
\hline Demokratis & $125(82,4)$ & & \\
\hline Otoriter & $18(11,1)$ & & \\
\hline Permisif & $10(6,5)$ & & \\
\hline \multicolumn{4}{|l|}{ Perilaku makan } \\
\hline Penyuka makanan & $111(72,5)$ & & \\
\hline Penghindar makanan & $42(27,5)$ & & \\
\hline \multicolumn{4}{|l|}{ Pendidikan ibu responden } \\
\hline SMP & $11(7,19)$ & & \\
\hline SMA & $67(43,79)$ & & \\
\hline Sarjana & $75(49,02)$ & & \\
\hline \multicolumn{4}{|l|}{ Pekerjaan ibu responden } \\
\hline Ibu rumah tangga & $85(55,56)$ & & \\
\hline Ibu bekerja & $68(44,44)$ & & \\
\hline \multicolumn{4}{|l|}{ Suku responden } \\
\hline Batak & $1(0,65)$ & & \\
\hline Jawa & $148(96,73)$ & & \\
\hline Melayu & $2(1,30)$ & & \\
\hline \multicolumn{4}{|l|}{ Sosial ekonomi } \\
\hline Kurang (< Rp 2.500.000,-) & $43(28,10)$ & & \\
\hline Cukup ( $\geq$ Rp 2.500.000,-) & $110(71,89)$ & & \\
\hline \multicolumn{4}{|l|}{ Jumlah anak } \\
\hline$\geq 3$ & $55(35,95)$ & & \\
\hline$\leq 2$ & $98(64,05)$ & & \\
\hline
\end{tabular}


Tabel 2. Korelasi antara pola asuh dengan perilaku makan anak,

\begin{tabular}{lcccc}
\hline Pola asuh & \multicolumn{2}{c}{ Perilaku makan } & koefisiensi korelasi $(\mathrm{r})$ & $\mathrm{p}$ \\
\cline { 2 - 5 } & $\begin{array}{c}\text { penyuka makanan } \\
\mathrm{n}(\%)\end{array}$ & $\begin{array}{c}\text { penghindar } \\
\text { makanan n }(\%)\end{array}$ & & \\
\hline demokratis & $96(76,8)$ & $29(23,2)$ & $0,197^{* *}$ & $0,013^{*}$ \\
permisif & $4(40)$ & $6(60)$ & $0,189^{* *}$ & $0,017^{*}$ \\
otoriter & $11(61,1)$ & $7(38,9)$ & 0,093 & 0,247 \\
\hline
\end{tabular}

Uji koefisien kontingensi, * korelasi bermakna $(\mathrm{p}<0,05),{ }^{* *}$ kekuatan korelasi sangat lemah

penelitian yang sama dengan penelitian ini. Sebanyak $111(72,5 \%)$ anak memiliki perilaku penyuka makanan. Sementara penghindar makanan $42(27,5 \%)$ anak.

Pola asuh orangtua diukur dengan cara wawancara menggunakan kuesioner pola asuh yang telah diadopsi dan dialihtatabahasa dari Parenting Style and Dimenions Questionnaire (PSDQ). Berdasarkan kuesioner yang diisi orang tua didapatkan responden pola asuh demokratis $125(82,4 \%)$, otoriter $18(11,1 \%)$ dan permisif 10 (6,5\%). Pendidikan ibu, aktivitas ibu dan sosial ekonomi keluarga tidak berbeda secara signifikan antara kelompok pola asuh ataupun perilaku makan ( $>0,05)$. Hasil analisis data hubungan antara pola asuh orangtua dalam hal ini demokratis, permisif, dan otoriter terhadap perilaku makan memiliki nilai kemaknaan $(\mathrm{p}=0,022)$ dengan kekuatan korelasi yang lemah $(\mathrm{r}=0,218)$.

Pola asuh demokratis memiliki korelasi sangat lemah dan signifikan terhadap perilaku makan penyuka makanan dan penghindar makanan, dengan arah korelasi positif $(r=0,197 ; p=0,013)$. Berdasarkan frekuensi penyuka makanan $(76,8 \%)$ lebih besar dibandingkan penghindar makanan $(23,2 \%)$ pada pola asuh demokratis menunjukkan adanya kecenderungan pola asuh demokratis terhadap perilaku penyuka makanan.

Pola asuh permisif memiliki korelasi sangat lemah dan signifikan terhadap perilaku makan penyuka makanan dan penghindar makanan, dengan arah korelasi positif $(r=0,197 ; \mathrm{p}=0,013)$. Berdasarkan frekuensi penyuka makanan $(40 \%)$ lebih kecil dibandingkan penghindar makanan $(60 \%)$ pada pola asuh permisif menunjukkan adanya kecenderungan pola asuh permisif terhadap perilaku penghindar makanan. Pola asuh otoriter, berdasarkan uji statistika tidak didapatkan korelasi yang signifikan baik terhadap perilaku makan meskipun jika dilihat dari nilai frekuensi penyuka makanan $(61,1 \%)$ lebih besar dibandingkan penghindar makanan $(38,9 \%)$ pada pola asuh otoriter.

\section{Pembahasan}

Pemilihan subyek penelitian usia 4-6 tahun karena usia ini merupakan periode perkembangan yang penting untuk mengadopsi kebiasaan makan yang baik karena perilaku dan preferensi makan yang terbentuk di periode ini kemungkinan akan bertahan di usia yang lebih besar. ${ }^{7,8}$

Sifat perkembangan anak yang cenderung senang bereksplorasi dengan hal baru memengaruhi perilaku makan anak. Hal tersebut menyebabkan anak terkadang bersikap terlalu pemilih, misalnya balita cenderung menyukai makanan ringan sehingga menjadi kenyang dan menolak makanan saat jam makan utama. Anak juga sering rewel dan memilih bermain saat orangtua memberikan makanan. Gangguan perilaku/pola makan tersebut dapat berkembang menjadi masalah kesulitan makan jika tidak segera diatasi. ${ }^{9}$ Sebuah studi acak pada praktek pribadi dokter anak, $60 \%$ orangtua yang memiliki anak usia 2 tahun, 30\% orang tua dengan anak usia 3 tahun dan $50 \%$ orang tua anak usia 4 tahun mengeluhkan masalah perilaku makan anak. ${ }^{10}$ Meskipun sebagian besar anak $(72,5 \%)$ memiliki perilaku makan penyuka makanan, tetapi penghindar makanan frekuensinya lebih kecil, yaitu $(27,5 \%)$ anak. Hal ini bisa menjadi keluhan orang tua apalagi jika berdampak pada status kesehatan dan gizi anak. Perilaku makan yang terbentuk dimasa kanak akan persisten, implikasi seperti kerewelan/ fussiness dan variasi makanan yang rendah atau responsif yang tinggi terhadap isyarat makanan dan peningkatan risiko obesitas. ${ }^{11}$ Perilaku penghindar makanan jika tidak segera diatasi bisa berdampak menjadi kelainan penghindar/pembatas makanan. Hal ini berkaitan dengan gagal tumbuh (baik tinggi maupun berat badan), defisiensi nutrisi dan atau ketergantungan pemberian makanan tambahan (baik oral maupun enteral), atau gangguan psikososial. ${ }^{12}$ 
Berdasarkan hasil pengukuran status gizi anak didapatkan kesan gizi baik $79,1 \%$, gizi lebih $6,5 \%$, obesitas $5,9 \%$, dan gizi kurang $8,5 \%$. Selain itu, juga didapatkan data perawakan pendek/stunting (tinggi badan di bawah standar menurut usia) sebesar $11,2 \%$. Data prevalensi masalah malnutrisi pada penelitian ini, tidak berbeda jauh dengan data Riset Kesehatan Dasar (Riskesdas) 2018. ${ }^{13}$

Orangtua adalah pendorong langsung kualitas makan anak dan akibatnya memiliki peran unik dalam pembentukan lingkungan makan anak. Gaya pengasuhan umum mengategorikan pola keseluruhan perilaku pengasuhan berdasarkan dua dimensi yaitu kontrol dan kehangatan/respon orang tua. Menurut Baumrind, ${ }^{14}$ ada tiga pola utama pengasuhan, yaitu demokratis (kontrol tinggi, kehangatan tinggi), otoriter (kontrol tinggi, kehangatan rendah) dan permisif (kontrol rendah, kehangatan tinggi). Pola asuh demokratis dianggap sebagai pola asuh terbaik dalam mendidik anak karena dianggap adanya keseimbangan antara kontrol dan kehangatan. Pola asuh demokratis adalah pola asuh yang memprioritaskan kepentingan anak, akan tetapi orangtua tidak ragu mengendalikan mereka. ${ }^{6,15}$

Sebanyak $125(81,7 \%)$ anak mendapatkan pola asuh demokratis, $18(11,85 \%)$ otoriter, dan 10 (6,5\%) permisif dari 153 subyek penelitian. Rhee $\mathrm{dkk}^{16}$ memaparkan frekuensi pola asuh di Amerika bahwa sebagian besar orang tua memberikan pola asuh otoriter $(48,9 \%)$ dibandingkan demokratis $(29,4 \%)$ dan pola asuh permisif $(21,7 \%)$. Berbeda dengan Kremers $\mathrm{dkk}^{1}$ yang melakukan penelitian di Belanda menyebutkan bahwa pola asuh terbanyak yang dipraktekkan pada anak adalah pola asuh demokratis $(46,3 \%)$ dibandingkan otoriter $(24,3 \%)$ dan permisif $(29,4 \%)$. Sebagian besar orang tua telah mengasuh anaknya dengan pola asuh terbaik berupa pola asuh demokratis meskipun dengan variasi latar belakang pendidikan, aktivitas, budaya/suku, dan sosial ekonomi keluarga. Literatur mengatakan bahwa pola asuh orang tua terhadap anaknya dipengaruhi oleh jenis kelamin, budaya, sosial ekonomi, pendidikan, aktivitas ibu dan jumlah saudara. ${ }^{6,15}$ Nilai budaya dapat memberikan gambaran umum atau pola awal yang dapat memandu orang tua dalam pengambilan keputusan dan praktek pengasuhan. Tiap kelompok etnis dapat memiliki pola pengasuhan anak yang berbeda dipengaruhi oleh norma budaya dan sosial budaya. Sebuah literatur penelitian di salah satu kampung adat Sunda yang masih memegang adat istiadat leluhumya, terdapat perbedaan pola asuh antara keluarga dengan mata pencaharian petani dan non-petani (pedagang, pengrajin anyaman dan pemandu). Keluarga petani menerapkan pola asuh otoriter, sedangkan keluarga non-petani menerapkan pola asuh demokratis, meskipun pada aspek tertentu menerapkan pola asuh otoriter. ${ }^{17}$ Sebuah penelitian pola asuh di salah satu kampung di Sumatera Selatan dengan latarbelakang sosial ekonomi rendah dan lingkungan geografis yang berat, orang tua mendidik anaknya secara keras (otoriter) dengan harapan dan alasan agar anaknya menjadi tangguh dan pekerja keras. ${ }^{18} \mathrm{Di}$ Amerika latin, umumnya digambarkan sebagai budaya yang menekankan rasa hormat dengan kewenangan orang tua dan aturan ketat dalam mendisiplinkan anak sehingga pola asuh otoriter lebih banyak digunakan. Selain itu, orang tua yang tidak bekerja, tingkat pendidikan rendah dan masih memegang teguh nilai budaya tradisional cenderung menggunakan pola asuh kontrol yang tinggi. ${ }^{19}$ Namun dalam penelitian ini tidak ditemukan perbedaan yang bermakna dari beberapa variasi latarbelakang orang tua.

Keluarga adalah lingkungan sosial terdekat dan orang tua merupakan perantara/agen sosialisasi anak yang paling penting. Keterlibatan orang tua penting sekali untuk untuk mencapai keberhasilan program pencegahan malnutrisi. Berdasarkan hasil penelitian ini, secara umum pola asuh dari orang tua yang terdiri dari demokratis, permisif dan otoriter memiliki hubungan bermakna terhadap perilaku makan anak, baik itu penyuka makanan dan penghindar makanan. Sebuah literatur mengatakan bahwa pengaruh secara global dari fungsi keluarga dan pola asuh dapat berdampak konsumsi makanan anak dan status gizi anak dan sebaliknya. ${ }^{16}$ Tahun 2005, Brann dan Skinner ${ }^{20}$ tidak menemukan perbedaan antara pola asuh dengan indeks massa tubuh anak yang rendah atau tinggi dan praktek pemberian makan. Pada tahun 2006 Montgomery dkk $^{21}$ gagal menemukan bukti hubungan kontrol orang tua dengan status gizi atau asupan kalori dengan sampel anak usia 4 tahun di Skotlandia. Namun, Rhee $\mathrm{dkk}^{16}$ tahun 2006 menemukan hubungan pola asuh terhadap risiko overweight. Tahun 2017, Podlesak $\mathrm{dkk}^{23}$ memaparkan adanya korelasi pola asuh dengan penyediaan akan kontrol atas makanan anak mereka, seperti meminta anak mereka untuk membantu merencanakan makan dan memungkinkan si anak untuk memilih apa yang harus dimakan dari makanan yang disajikan, sambil mempertahankan lingkungan makan yang positif dengan memuji anak dan membuat makanan yang menyenangkan. Beberapa literatur tidak konsisten 
karena perbedaan metode penelitian, pengukuran dan jumlah sampel dengan perbedaan latar belakang, pendidikan, sosial ekonomi, usia dan status indeks massa tubuh. ${ }^{21}$ Birch dkk, ${ }^{24}$ juga memberikan bukti eksperimental pertama bahwa penggunaan praktek pembatasan makan oleh orang tua tidaklah produktif. Hal ini meningkatkan asupan makanan terbatas anak prasekolah dan merupakan faktor risiko kenaikan berat badan yang berlebihan.

Secara spesifik, setelah dilakukan uji korelasi antara jenis pola asuh terhadap perilaku makan anak, tidak semua jenis pola asuh berhubungan dengan perilaku makan anak. Pola asuh demokratis berkorelasi sangat lemah terhadap perilaku makan anak. Jika dilihat dari nilai frekuensi perilaku penyuka makan lebih besar dibandingkan penghindar makan pada pola asuh orang tua yang demokratis, hal ini tidak berbeda dengan beberapa penelitian sebelumnya. Dalam literatur pengasuhan umum, gaya pengasuhan demokratis telah berulangkali dikaitkan dengan hasil positif, termasuk prestasi akademik yang tinggi, lebih sedikit perilaku remaja berisiko tinggi dan kematangan anak yang lebih besar. ${ }^{25}$ Khusus untuk kesehatan, pola asuh demokratis telah dikaitkan dengan peningkatan status berat badan ${ }^{5}$ dan dapat berfungsi sebagai moderator hubungan antara praktik pemberian makan dan konsumsi buah dan sayur anak dalam rangka mengatasi obesitas yang prevalensinya cenderung meningkat. ${ }^{6}$ Selain itu pola asuh demokratis dapat memperbaiki perilaku makan ${ }^{26}$ dan berhubungan dengan rendahnya risiko obesitas. ${ }^{27}$

Sehubungan dengan pemberian makan, orang tua yang demokratis menggunakan dorongan, menyeimbangkan kontrol dan otonomi anak, memberikan contoh konsumsi makanan sehat dan menyediakan berbagai macam buah dan sayuran di rumah. ${ }^{23,28}$ Beberapa penelitian di negara maju, mengatakan adanya hubungan pola asuh dengan perilaku makan baik yang berfokus pada asupan buahbuahan dan sayuran. Hal ini terkait dengan prevalensi obesitas yang meningkat di negara maju. Seperti penelitian yang dilakukan oleh Kremers $\mathrm{dkk}^{1}$ dan Pearson $\mathrm{dkk}^{26}$. Pola asuh demokratis memiliki kecenderungan akan perilaku penyuka makanan dikarenakan pola asuh demokratis memberikan rasa nyaman pada anak dimana anak diberi kebebasan dalam memilih makanan namun masih dalam kontrol orang tua.

Pola asuh permisif berkorelasi sangat lemah terhadap perilaku makan anak. Jika dilihat dari nilai frekuensi perilaku, penghindar makan lebih besar dibandingkan penyuka makan, tidak berbeda dengan beberapa penelitian sebelumnya. Orang tua dengan pola asuh permisif biasanya bersifat hangat sehingga seringkali disukai oleh anak. Pola asuh permisif merupakan pola asuh ketika orang tua serba membolehkan anak berbuat apa saja. Orang tua memiliki kehangatan dan menerima apa adanya. Kehangatan cenderung memanjakan, dituruti keinginannya. Sementara menerima apa adanya akan cenderung memberikan kebebasan kepada anak untuk berbuat apa saja. Pola asuh seperti ini dapat menghasilkan karakteristik anak yang tidak patuh, manja, memiliki pola makan yang tidak teratur. ${ }^{5,6,15}$ Penelitian sebelumnya menemukan bahwa pola asuh permisif berkaitan dengan tingginya konsumsi makanan yang densitas gizinya rendah dan konsumsi buah yang buruk. ${ }^{29}$ Podlesak $\mathrm{dkk}^{23}$ menunjukkan bahwa terdapat korelasi positif antara pola asuh permisif dengan kecenderungan pemilih makanan. Selain itu, orang tua yang permisif lebih toleran, memberikan hadiah untuk makan dan berkorelasi negatif dengan pemodelan asupan makanan. ${ }^{23,28}$

Pola asuh otoriter, berdasarkan uji statistik tidak didapatkan korelasi bermakna baik terhadap perilaku penyuka makanan ataupun penghindar makanan. Pola asuh otoriter terkait dengan strategi pemberian makan yang negatif, seperti kontrol, tekanan untuk makan, pembatasan, penghargaan untuk makan dan ketersediaan buah dan sayuran yang rendah. ${ }^{23}$ Tipe pola asuh ini tidak nyaman karena perasaan anak yang cenderung tertekan, sehingga anak tidak memiliki kemandirian dalam memilih makanan. ${ }^{6,15}$ Pola asuh terhadap perilaku makan anak pada penelitian ini tidak berkorelasi dengan penelitian sebelumnya dikarenakan karakteristik budaya di Indonesia yang berbeda dengan penelitian sebelumnya yang dilakukan dibeberapa negara maju. Podlesak $\mathrm{dkk}^{23}$ juga menunjukkan bahwa terdapat korelasi positif antara pola asuh otoriter dengan kecenderungan pemilih makanan. Sebuah penelitian di Amerika latin juga mengatakan pola asuh dengan tekanan dan kontrol yang terlalu tinggi menimbulkan kecenderungan anak untuk makan makanan yang tidak sehat. ${ }^{19}$ Orang tua dengan gaya makan otoriter cenderung membuat tuntutan terhadap anak mereka selama makan dan tidak responsif terhadap preferensi, emosi atau kebutuhan anak mereka. Namun, tuntutan ini tidak terkait dengan kualitas makanan secara keseluruhan atau konsistensi dengan pilihan makanan yang sehat. ${ }^{30}$

Korelasi yang sangat lemah antara pola asuh dan perilaku makan dikarenakan banyak faktor yang berpengaruh terhadap perilaku makan, seperti sosial ekonomi keluarga, tingkat pendidikan orang tua, 
budaya orang tua dan lingkungan sekitar, informasi dari media massa, perilaku makan di lingkungan keluarga, teman sebaya dan sekitarnya. Oleh sebab itu, pola asuh hanyalah salah satu dari sekian banyak faktor yang berpengaruh terhadap perilaku makan anak. Beberapa faktor belum dapat dikendalikan peneliti dan menjadi keterbatasan dalam penelitian ini. Penelitian ini merupakan hasil laporan/evaluasi orang tua tentang perilaku makan anak. Persepsi orangtua terhadap perilaku makan anak tentu bervariasi dibandingkan evaluasi dari anak itu sendiri. Kemudian perbedaan budaya di Indonesia dengan luar negeri terutama negara maju harus dipertimbangkan.

Keterbatasan lain penelitian ini adalah adanya efek Hawthorne dalam penelitian survei ketika reponden memberikan respon atau jawaban dimodifikasi/tidak sesuai dengan kenyataan karena menyadari sebagai obyek yang diobservasi, walaupun sudah diupayakan diberikan pengarahan untuk menjawab sesuai dengan kenyataan. Penilaian perilaku makan didasarkan pada pendapat subyektif ibu, meskipun analisis disesuaikan untuk beberapa karakteristik ibu, tidak dapat dikesampingkan sepenuhnya bahwa kesejahteraan ibu dan sikapnya tentang kesehatan memengaruhi penilaiannya terhadap perilaku makan anak.

\section{Kesimpulan}

Dari penelitian ini dapat disimpulkan bahwa terdapat korelasi sangat lemah pola asuh demokratis dan pola asuh permisif terhadap perilaku makan anak.

\section{Daftar pustaka}

1. Kremers SPJ, Brug J, Vries H, Engels RCME. Parenting style and adolescent fruit consumption. Appetite 2003;41:43-50.

2. Scaglioni S, Salvioni M, Galimberti C. Influence of parental attitudes in the development of children eating behavior. Brit J Nutr 2008;99:S22-5.

3. Soetjiningsih. Faktor-faktor yang Mempengaruhi Tumbuh Kembang. Dalam: Soetjiningsih, Ranuh IG, penyunting. Tumbuh Kembang Anak. Ed 2. Jakarta: EGC; 2013.h.61-72.

4. Piazza CC. Feeding disorders and behavior: what have we learned? Dev Disabil Res Rev 2008;14:174-81.

5. Maccoby ED, Martin JA. Socialization in the context of the family: parent-child interaction. In Socialization, personality and social development. Dalam: Mussen PH, Hetherington
EM, penyunting. Manual of child psychology. vol 4. New York: John Wiley and Sons; 1983.h.1-101

6. Baumrind D. Child care practices anteceding three patterns of preschool behavior. Genetic Psychology Monographs. 1967;75: 43-88.

7. Northstone K, Emmett PM. Are dietary patterns stable throughout early and mid-childhood? A birth cohort study. Br J Nutr 2008;100:1069-76.

8. Arlinghaus KR, Vollrath K, Hernandez DC. Authoritative parent feeding style is associated with better child dietary quality at dinner among low-income minority families. Am J Clin Nutr 2018;108:730-6.

9. Dewi SK, Soetjiningsih. Kesulitan makan pada anak. Dalam: Soetjiningsih, Ranuh IG, penyunting. Tumbuh Kembang Anak. Edisi kedua. IDAI: Sagung Seto; 2013.h.325-36.

10. Schroeder CS, Gordon BN. Assesment and treatment of chidhood problems. Edisi ke-2. London: The Guilford Press; 2002. h.81-114.

11. Finnane, JM., Jansen E, Mallan KM, Daniels LA. Mealtime structure and responsive feeding practices are associated with less food fussiness and more food enjoyment in children. J. Nutr. Educ. Behav 2017;49:11-18.

12. Spettigue W, Norris ML, Santos A, Obeid N. Treatment of children and adolescents with avoidant/restrictive food intake disorder: a case series examining the feasibility of family therapy and adjuctive treatments. J Eating Disorders 2018;6:1-11.

13. Kementerian Kesehatan RI. Penyajian Pokok-Pokok Hasil Riset Kesehatan Dasar. Jakarta: Badan Penelitian dan Pengembangan Kesehatan Kementerian Kesehatan RI; 2018.

14. Baumrind D. Rearing competent children. Dalam: Damon W, penyunting. Child development today and tomorrow. San Francisco (CA): Jossey Bass; 1989.h.349-78.

15. Darling N, Steinberg L: Parenting style as context: An integrative model. Psychological Bulletin 1993;113:487-96.

16. Rhee K. Childhood overweight and the relationship between parent behaviors, parenting style and family functioning. AAPSS 2008;615:11-37.

17. Ruqayah F. Pola asuhan anak dalam penanaman nilai-nilai pada masyarakat kampung Naga. J local culture 2015;2:63-80.

18. Putra MR. Pengasuhan anak usia 5-6 tahun di Kampung Tapak Lebar Sumatera Selatan. Jurnal Pendidikan Usia Dini 2016;10:29-44.

19. Arredondo EM, Elder JP, Ayala GX, Campell N, Baquero $\mathrm{B}$, Duerksen $\mathrm{S}$. Is parenting style related to children's eating and physical activity in latino families? Health Edu Res 2006;21:862-871.

20. Brann LS, Skinner JD. More controlling child-feeding practices are found among parents of boys with an average body mass index compared with parents of boys with a high body mass index. J the American Dietetic Association 2005;105:1411-16.

21. Montgomery C, Jackson DM, Kelly LA, Reilly JJ. Parental feeding style, energy intake and weight status in young Scottish children. Brit J Nutr 2006;96:1149-53.

22. Wardle J, Guthrie CA, Sanderson S, Rapoport L. Development of the children's eating behavior questionnaire. J. Child Psychol 
Psychiat 2001;42:963-70.

23. Podlesak AKM, Mozer ME, Smith-Simpson S, Lee SY, Donovan SM. Associations between parenting style and parent and toddler mealtime behaviors. Curr Dev Nutr 2017;1:1-7

24. Birch LL. Development of food preferences. Annu Rev Nutr 1999;19:41-62.

25. Mandara J. The typological approach in child and family psychology: a review of theory, methods, and research. Clin Child Fam Psychol Rev 2003;6:129-46.

26. Pearson N, Atkin AJ, Biddle SJ, Gorely T, Edwardson C. Parenting styles, family structure and adolescent dietary behaviour. Public Health Nutr 2010;13: 1245-53.

27. Rhee KE, Lumeng JC, Appugliese DP, Kaciroti N, Bradley RH. Parenting styles and overweight status in first grade. Pediatrics
2006;117: 2047-54.

28. Hubbs-Tait L, Kennedy TS, Page MC, Topham GL, Harrist AW. Parental feeding practices predict authoritative, authoritarian, and permissive parenting styles. J Am Diet Assoc 2008;108:1154-61.

29. Hennessy E, Hughes SO, Goldberg JP, Hyatt RR, Economos CD. Permissive parental feeding behavior is associated with an increase in intake of low-nutrient-dense foods among American children living in rural communities. J Acad Nutr Diet 2012;112:142-8.

30. Arlinghaus KR, Vollrath K, Hernandez DC. Authoritative parent feeding style is associated with better child dietary quality at dinner among low-income minority families. Am J Clin Nutr 2018;108:730-36. 